\title{
EVALUASI EKONOMI MIKRO: DAMPAK PROYEK TERPADU PETERNAKAN DAN PERTANIAN PANGAN DI INDONESIA BAGIAN TIMUR
}

\author{
Budiman Notoatmojo ${ }^{1}$
}

\begin{abstract}
Impact evaluation of integrated livestock and food crop project micro analysis will concentrate in the increase of farmers income, the increase of farmers food nutrient, and woman participation. Macro analysis has also been used to study on decentralization. The project has given 41.800 cattles for 19.000 farmers, 20.000 goats for 9000 farmers, construct infrastructures (village road system, livestoc holding ground, etc), facilitate agroinputs for 28,000 package, training and extensions, and more others with total cost about US\$34,200,000. The area covers South Sulawesi, North Sulawesi, Gorontalo, Maluku, and North East Maluku. Total number of samples which have been taken for the survey were 162, which consist of 27 women, 63 farmers, 18 project staf, and 18 respondent from outside project. The result from the survey has shown that farmers have got benefits from project and their income has increased. 79\% farmers has satisfied with the credit they have received already, however, the repayment has moved slowly. Eventhough they have raised only chicken, however, the farmers' food nutrient has increased already.
\end{abstract}

Keywords: micro economy, integrated project, livestock, food crop

\section{ABSTRAK}

Evaluasi dampak proyek terpadu analisis mikro peternakan dan pertanian pangan memfokuskan pada peingkatan pendapatan petani, peningkatan gizi petani, dan partisipasi perempuan. Analisis makro juga telah digunakan untuk mempelajari masalah desentralisasi. Proyek tersebut telah memberikan 41.800 ternak untuk 19.000 petani, 20.000 kambing untuk 9.000 petani, membangun infrastruktur (jalan raya desa, tanah milik peternak, dan lain lain), pelatihan, dan kegiatan lainnya yang menghabiskan dana sekitar 34.200.000 dolar Amerika. Areanya meliputi Sulawesi Selatan, Sulawesi Utara, Gorontalo, Maluku, dan Maluku Timur Laut. Sampel yang diambil sebanyak 162 orang yang terdiri dari 27 perempuan, 63 petani, 18 staf prroyek, dan 18 responden dari luar proyek. Hasilnyaa, petani memperoleh manfaat dari proyek tersebut dan pendapatan mereka meningkat. $79 \%$ petani sangat puas dengan pemberian kredit yang mereka terima meskipun pembayaran cicilannya sedikit lambat. Gizi para petapijuga/ meningkat.

Kata kunci: ekonomi mikro, proyek terpadu, peternakan, pertanian pangan

\footnotetext{
${ }^{1}$ Peneliti Senior Balitbang Deptan RI \& Staf Pengajar Fakultas Ekonomi, UBiNus, Jakarta
} 


\section{PENDAHULUAN}

Dalam Rangka pemerataan pembangunan di Indonesia, Kawasan Timur Indonesia (KTI) merupakan kawasan yang menjadi prioritas untuk dipacu pengembangannya guna memperkecil ketinggalannya dari Kawasan Barat atau Kawasan lainnya di Indonesia. Percepatan pembangunan di kawasan itu dapat menyeimbangkan derap pembangunan di Indonesia, sekaligus memanfaatkan potensi yang tersedia di Kawasan itu untuk meningkatkan kesejahteraan masyarakat luas. Salah satu upaya Pemerintah untuk mempercepat pembangunan Kawasan Timur Indonesia itu adalah dengan melaksanakan Proyek Pengembangan Usaha tani dan Ternak (PUTKATI) di Kawasan itu. Proyek Pengembangan Usaha tani dan Ternak merupakan proyek terpadu yang melibatkan tiga subsektor, yaitu subsektor peternakan sebagai leading subsektor dan subsektor perkebunan dan tanaman pangan dan hortikultura sebagai subsektor pendukung.

Tujuan proyek adalah meningkatkan pendapatan petani berpendapatan rendah dilokasi proyek; pembangunan usaha tani sebagai unit usaha terpadu; pemanfaatan sumber daya lahan secara berdaya guna dan berhasil guna; meningkatkan populasi ternak dan pemerataan pendapatan petani. Dalam rangka mencapai tujuan tersebut, Proyek Pengembangan Usaha tani dan Ternak (PUTKATI) mengembangkan dan melaksanakan berbagai komponen kegiatan diantaranya adalah (a) Penyebaran ternak sapi sebanyak 41.800 ekor kepada 19.000 petani dan 20.000 ekor kambing kepada 9.000 petani; (b) Membangun dan meningkatkan prasarana dan sarana penunjang yang meliputi empat buah holding ground, 14 buah satuan pelayanan terpadu, 9 buah poskeswan, 33 pos pembantu pelayanan kesehatan hewan dan pembangunan jalan desa $100 \mathrm{~km}$ dan lima buah jembatan gantung; (c) menyediakan agro input sebanyak 28000 paket; (d) Mengadakan fasilitas penunjang yang melliputi kendaraan bermotor, peralatan pertanian, peralatan penyuluhan, peralatan kantor dan peralatan IB; (e) Meningkatkan kelembagaan petani; (f) meningkatkan pengetahuan dan keterampilan petani dan petugas proyek melaui pelatihan dan penyuluhan; (g) Pengembangan produksi vaksin penyakit Jembrana di BPPH Denpasar melalui penyediaan peralatan laboratorium; (h) Menyediakan jasa konsultan.

Pembiayaan proyek seluruhnya berjumlah US\$34,260,000. yang berasal dari dana IFAD sebesar US\$ 13,800,000; IDB US\$ 6,8484,000. Pemerintah New Zealand sebesar US\$ 1,401,000. dan dana Pemerintah RI sebesar US\$ 12,208,000. Evaluasi dampak proyek didesain untuk menyusun suatu data dasar (base line data) tentang sumber daya pertanian yang ada di lokasi proyek yang meliputi sumber daya ternak, usaha tani, sumber daya manusia (petani dan petugas), kelembagaan petani, pola pertanian, pendapatan, serta faktor sosial kelompok sasaran (target group) yang terlibat dalam proyek. Data tersebut dipergunakan sebagai suatu standard penelitian dalam mengevaluasi dampak proyek.

Dampak proyek yang akan dievaluasi didasarkan pada rekomendasi hasil supervisi UNOPS yang meliputi peningkatan gizi dan ketahanan pangan keluarga, peranan wanita tani dalam menunjang kegiatan proyek, dampak proyek terhadap peningkatan pendapatan keluarga, dampak pelatihan petani/kelompok tani dan staf proyek terhadap peningkatan sumber daya manusia dalam menunjang pelaksanaan kegiatan proyek, dan pengaruh desentralisasi terhadap pelaksanaan proyek. 


\section{PEMBAHASAN}

\section{Tujuan Evaluasi Ekonomi Mikro Dampak Proyek}

\section{Tujuan Evaluasi}

1. Untuk mengukur manfaat sosial dan ekonomi yang diperoleh petani peserta dengan adanya proyek yang meliputi berikut ini.

a. peningkatan pendapatan petani melalui sistem usaha tani terpadu dengan adanya penyebaran ternak dan agro input.

b. Peningkatan gizi dan ketahanan pangan keluarga.

c. Peningkatan harkat wanita (jender) melalui keterlibatan wanita tani secara aktif baik dalam kegiatan proyek, maupun kegiatan sosial lainnya.

d. Peningkatan sumber daya manusia, pengetahuan, dan keterampilan, serta sikap (petani dan staf proyek) melalui pelatihan dan pembinaan.

2. Mengidentifikasikan hambatan atau kelemahan dalam pelaksanaan kegiatan proyek yang mempengaruhi pencapaian tujuan proyek.

3. Meneliti pengaruh kebijakan desentralisasi terhadap organisasi dan manajemen proyek dan pelaksanaan kegiatan di lapangan.

\section{Kegiatan yang Dilaksanakan}

Dalam upaya mengadakan Evaluasi Ekonomi Mikro Dampak Proyek PUTKATI maka dilakukan kegiatan berikut.

1. Mengidentifikasi dampak proyek terhadap peningkatan gizi dan ketahanan pangan keluarga dengan mengukur tingkat produksi pangan melalui sistem usaha tani terpadu, pola menabung individu maupun kelompok, keterlibatan wanita tani dalam mendukung usaha tani.

2. Melakukan evaluasi terhadap dampak realisasi pelaksanaan pelatihan dalam upaya peningkatan sumber daya petani dan staf proyek.

3. Melakukan evaluasi dampak ekonomi terhadap pengembangan masyarakat penerima bantuan (beneficiaries community development) yang meliputi pemanfaatan ternak dalam mendukung pola usaha tani terpadu dalam kelompok, peningkatan pendapatan petani melalui usaha tani terpadu, pengembangan kelompok, dan lain-lain.

4. Melakukan evaluasi terhadap kebijakan desentralisasi yang mempengaruhi pelaksanaan proyek.

5. Berdasarkan hasil evaluasi, menyusun rekomendasi bagi pelaksanaan proyek selanjutnya.

\section{Keluaran (Output)}

Output studi evaluasi Ekonomi Mikro dampak proyek sebagai berikut. Laporan hasil evaluasi dampak proyek yang disusun dalam bahasa Indonesia dan bahasa Inggris yang berisikan (1) Hasil evaluasi Ekonomi Mikro dampak proyek dengan rekomendasinya; (2) Rekomendasi bagi pelaksanaan proyek selanjutnya; (3) Rekomendasi bagi penyusunan laporan akhir proyek (project completion report); (4) Format base line data usaha tani. 


\section{Metode Penelitian}

\section{Pendekatan}

Pendekatan yang dipakai meliputi aspek (1) Lokasi penelitian; (2) Klasifikasi wilayah penelitian berdasarkan zona; (3) Kerangka penarikan contoh dan jumlah responden; (4) Pengelompokkan rumah tangga petani berdasarkan luas penguasaan lahan dan pendapatan per kapita; dan (5) Metode analisis data. Hasil analisis dijadikan dasar untuk mengevaluasi dampak proyek PUTKATI pada masing-masing wilayah.

Pendekatan logical framework (log-frame) digunakan agar kegiatan ini dapat dilaksanakan dengan hasil yang terukur (accountable) log-frame baseline disajikan pada Lampiran I yang mencakup tujuan akhir (goal), manfaat (outcomes), luaran (outputs) kegiatan (activities) (Fardiaz dkk., 1999). Benchmark survey didasarkan pada hasil surpervisi UNOPS.

Survey dilakukan dengan kuesioner terstruktur dan semi struktur. Pengumpulan data primer di tingkat petani maupun informan kunci dilakukan dengan wawancara yang mencakup berikut ini.

1. Sumber daya yang ada;

2. penggunaan sumber daya;

3. rumah tangga;

4. sasaran dan keinginan (di) rumah tangga petani;

5. komunitas;

6. dukungan kelembagaan;

7. masalah dan kendala;

8. kesempatan untuk perbaikan/pengembangan.

\section{Lokasi Penelitian}

Lokasi proyek meliputi propinsi Sulawesi Utara (Kabupaten Minahasa, Bolaang Mongondow), Propinsi Gorontalo (Kabupaten Gorontalo dan Bualerno), Propinsi Sulawesi Selatan (Kabupaten Bulukumba, Polmas, Mamuju, Luwu, dan Luwu Utara).

\section{Klasifikasi Dampak Proyek}

Klasifikasi dampak proyek berdasar rekomendasi hasil supervisi UNOPS yang meliputi peningkatan gizi dan ketahanan pangan, peranan wanita tani, pendapatan keluarga tani, hasil pelatihan, dan pengaruh desentralisasi dari hasil pelaksanaan proyek

\section{Penarikan Contoh dan Metode Analisis}

Penarikan contoh acak lengkap berdasar klasifikasi dampak dan target group maka system stratified purposive random sampling akan dilakukan. Stratifikasi berdasar target group penerima proyek dan tidak penerima proyek, petani, wanita tani, staf proyek (untuk dampak pelatihan) staf di dalam dan di luar proyek (untuk dampak desentralisasi), dan stratifikasi berdasar lokasi. Secara skematis pelaksanaan survei di tingkat Propinsi, Kabupaten dan di desa lokasi usaha tani digambarkan dalam Bagan 1 berikut. 


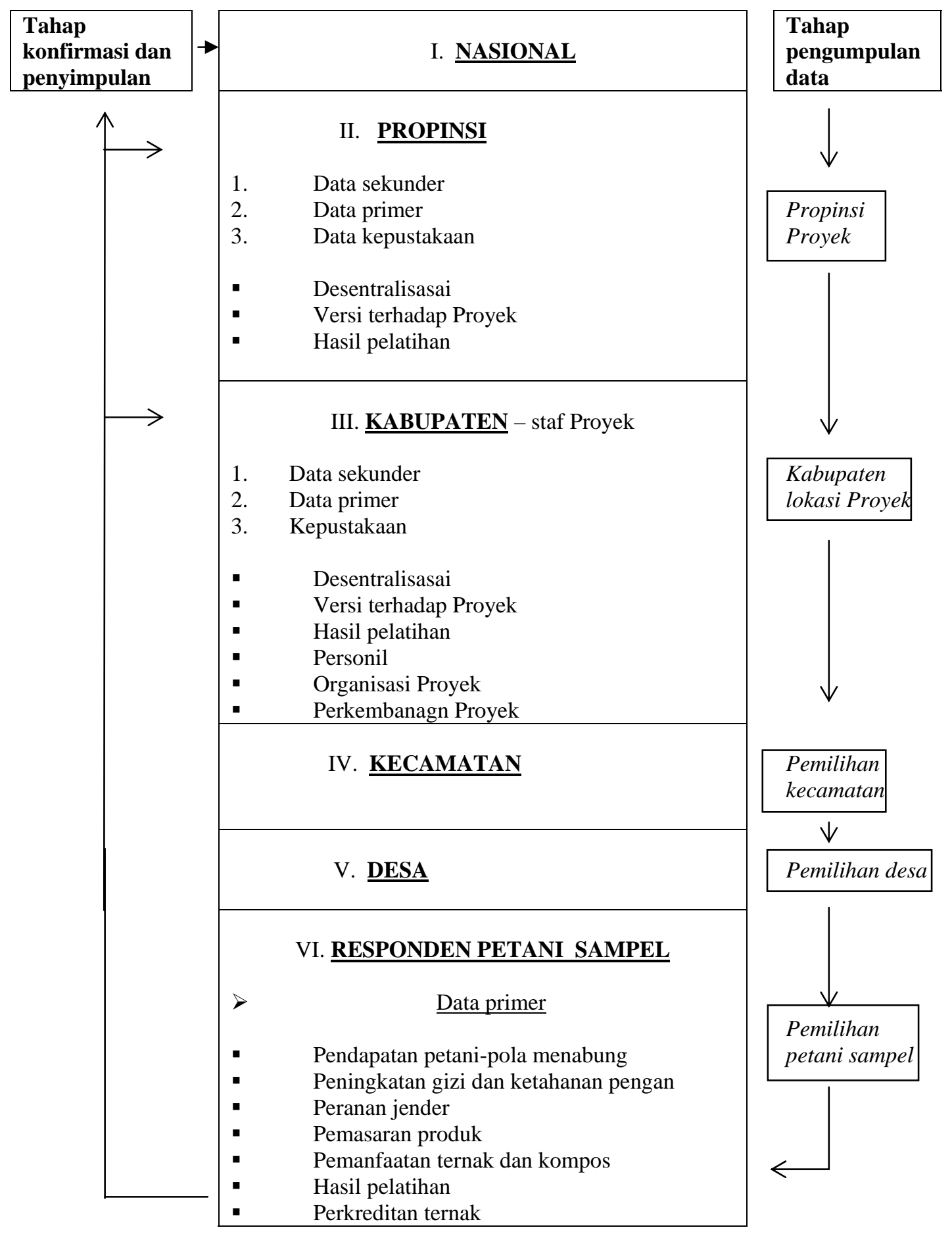

Bagan 1 Prosedur survei Evaluasi Dampak Proyek Secara Struktur Hierarkis di Propinsi Sulawesi Utara, Gorontalo, dan Sulawesi Selatan 
Survei dilakukan dengan kuesioner terstruktur dan semi-struktur. Pengumpulan data primer di tingkat petani maupun informan kunci dilakukan dengan wawancara yang mencakup (1) Karakteristik rumah tangga tani; (2) Struktur penguasaan lahan; (3) Struktur pendapatan; (4) Struktur pengeluaran; (5) Tingkat penerapan teknologi dan struktur ongkos; (6) Persepsi petani; dan (7) Kendala. Jumlah responden mencapai 162 yang terbagi atas wanita tani 27, petani 63, staf proyek 18, dan staf diluar proyek 18, dan respoden di luar proyek sebanyak 36 orang. Di samping itu, dilakukan wawancara kepada kelompok tani, kelompok petani Putkati, dan kelompok wanita tani/arisan/simpan pinjam. Metode analisis yang digunakan adalah analisis before dan after proyek, yang didasarkan pada rekomendasi hasil supervisi UNOPS. Analisis deskriptif dan tabulasi silang digunakan untuk memperoleh informasi yang komprehensif tentang data hasil evaluasi dampak proyek. Analisis finansial digunakan untuk membangun struktur usaha tani beberapa komoditas unggulan.

Untuk mengukur indikator dampak digunakan analisis regresi multifaktor dan pembanding antara data dasar dan data akhir proyek, data di dalam proyek, dan di luar proyek. Indikator pendapatan petani diukur melalui analisis usaha tani. Adapun analisis regresi terinci sebagai berikut.

$$
Y=a+b\left(X_{1}-X_{1}\right)+c\left(X_{2} X_{2}\right)+d\left(X_{3} X_{3}\right)+e\left(X_{4} X_{4}\right)+f\left(X_{5}-X_{5}\right)+g\left(X_{6} X_{6}\right)+e 1
$$

Dim atra $x_{1}$ le pendapatan petati hasil proyek $x_{1}=$ pendapatan petani sebelunt proyek $X_{2}$ dan $X_{2}=$ peringkatan gizi sesudah dan sebelum proyek

$\mathrm{X}_{3} \mathrm{ldath} \mathrm{X} 3=$ peratran watrita sesudah dan sebelutn proyek

$X_{4}$ dan $X 4=$ hasil segudah dan sebelum pelatihat

$X$ f dan $X S=$ penganth desentralisasi sesudah dan sebelum proyek

$X_{0}{ }_{1}$ an $X 6=$ pengatuh kredit. sesudah dan sebelum froyek

Data yang dikumpulkan adalah data time series (sebelum dan sesudah proyek) dan cross section (antara lokasi). Dari hasil analisis data dan survei lapang ternyata variabel Y dan X1 perlu determinasi lebih lanjut sehingga fungsi regresi terobah sebagai berikut.

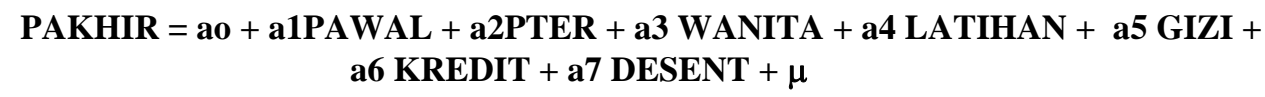

PAKHIR = Pendapatan akhir petani setelah mendapatkan paket agro- input (Rp.000,-) (ex-post analisis)

PAWAL = Pendapatan petani sebelum mendapatkan agro-input (Rp.000,-) (ex-ante analisis).

PTER = Pendapatan usaha ternak dari hasil pengelolaan paket proyek (Rp.000,-)

WANITA = Dampak peranan wanita petani proyek (hasil scoring)

LATIHAN = Dampak pelatihan yang diberikan pada petani proyek (hasil scoring)

GIZI = Dampak perubahan gizi petani proyek (hasil scoring)

KREDIT = Akses pengembalian kredit sesuai rekomendasi (hasil scoring) dan,

DESENT = Pengaruh desentralisasi (peubah dummy dimana $0=$ lokasi yang belum aktif dalam pengelolaan proyek, 


dan 1 = lokasi yang telah aktif dalam pengelolaan
proyek)
$=$ Intersep
$\begin{aligned} \text { ao } & =\text { Parameter estimasi } \\ \text { a1, a2, a3,a4,a5, a6, a7 } \quad & \text { Peubah pengganggu } \\ \mu & \end{aligned}$

\section{Organisasi Pelaporan}

Pada kegiatan ini, sistem pelaporannya terdiri dari berikut ini.

1. Pembuatan proposal;

2. pembuatan kuesioner;

3. uji coba kuesioner;

4. menentukan kerangka dan pengambilan contoh;

5. survei;

6. data entry dan analisis;

7. seminar; dan

8. penulisan laporan akhir.

\section{Hasil dan Pembahasan}

\section{Karakteristik Petani Proyek PUTKATI di Lokasi Pengembangan}

Karakteristik petani dapat digunakan sebagai indikator dalam untuk menggambarkan sejauh mana petani tersebut ikut berpartisipasi di dalam kegiatan Proyek Putkati dan sejauh mana tingkat keberhasilan dalam pengelolaan proyek yang direkomendasikan.

Tabel 1 Karakteristik Petani Peserta Proyek PUTKATI

di Propinsi Sulawesi Utara, Gorontalo, dan Sulawesi Selatan

\begin{tabular}{lccc}
\hline \hline Peubah & Sulawesi Utara & Gorontalo & Sulawesi Selatan \\
\hline Jumlah anggota keluarga (jiwa) & 3.38 & 4.28 & 4.20 \\
Pengalaman usaha ternak (tahun) & 1.70 & 6.00 & 4.42 \\
Pekerjaan pokok (persen) & & & \\
$\quad$ - Petani penggarap & 92 & 100 & 80.00 \\
$\quad$ - Pedagang & - & - & 8.50 \\
$\quad$ - Buruh tani & & - & 11.5 \\
Pejerjaan sambilan (persen) & 23.07 & 14.28 & 17.14 \\
$\quad$ - Pedagang & - & - & 8.5 \\
$\quad$ - Buruh tani & 15.30 & 28.57 & 14.5 \\
$\quad$ Lainnya & & & \\
\hline \hline
\end{tabular}

Evalua si Ekonomi Mikro: Dampak Proyek... (Budiman Notoatmojo) 


\section{Penguasaan Sumber daya Lahan yang Dimiliki Peserta Proyek}

Lahan merupakan faktor penting (asset) dalam kegiatan/aktivitas penduduk pedesaan khususnya kaitannya dalam mendukung ekonomi penduduk di pedesaan. Secara rinci penguasaan sumber daya lahan yang dimiliki petrani peserta Proyek digambarkan dalam Tabel 2 berikut.

Tabel 2 Penguasaan Sumber daya Lahan yang Dimiliki Petani Proyek PUTKATI di Propinsi Sulawesi Utara, Gorontalo, dan Sulawesi Selatan (m2)

\begin{tabular}{|c|c|c|c|c|c|c|c|c|c|c|c|c|}
\hline \multirow{2}{*}{$\begin{array}{l}\text { Propinsi } \\
\text { Peubah }\end{array}$} & \multicolumn{3}{|c|}{ Sulawesi Utara } & \multicolumn{3}{|c|}{ Gorontalo } & \multicolumn{6}{|c|}{ Sulawesi Selatan } \\
\hline & 01 & 02 & Rataan & 03 & 04 & Rataan & 05 & 06 & 07 & 08 & 09 & Rataan \\
\hline Sawah & - & 7.142 & 3.845 & 4.000 & - & & 1.000 & 4.250 & - & 9.714 & 6.785 & 4.349 \\
\hline$\%$ & - & (85) & 5) & (43) & - & 5) & (28) & (28) & - & 0) & (100) & $.2)$ \\
\hline Tegalan & 000 & 7.140 & 7.536 & 10.700 & 11.428 & 54 & 13.857 & 18.335 & 12.500 & 3.330 & 4.071 & 10 \\
\hline$\%$ & (100) & $(100)$ & $(100)$ & (71) & 0) & 5) & $(100)$ & (86) & & (86) & (100) & (94 \\
\hline Pekarangan & 750 & 834 & 795 & 2.622 & 3.461 & 3. & 3.461 & 700 & 2.500 & 1.366 & 2.633 & 2.132 \\
\hline$\%$ & (50) & (71) & $(60.5)$ & (100) & (57) & (78.5) & (57) & (43) & (100) & (43) & (86) & (65.8) \\
\hline Kebun & 5.000 & - & 230 & 1.225 & - & 612 & - & - & - & - & - & - \\
\hline$\%$ & (16 & - & (8) & (29) & . & (14.5) & 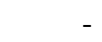 & - & - & - & - & \\
\hline otal & 250 & 5.116 & 2.406 & 18.547 & 14.889 & 16.717 & 18.318 & 23.285 & 15.000 & 14.410 & 13.489 & 16.899 \\
\hline
\end{tabular}

$\begin{array}{lll}\text { Keterangan : } \quad 01=\text { Kabupaten Minahasa } & 03=\text { Kabupaten Boalemo } & 05=\text { Kabupaten Bulukumba } \\ 02=\text { Kabupaten B. Mongondow } & 04=\text { Kabupaten Gorontalo } & \begin{array}{l}06=\text { Kabupaten Polmas } \\ 07=\text { Kabupaten Mamuju } \\ \end{array} \\ & & 08=\text { Kabupaten Luwu } \\ & 09=\text { Kab. Luwu Utara }\end{array}$

\section{Perkembangan Komoditas Ternak oleh Peserta Proyek Putkati}

Inventarisasi sumber daya ternak pada petani peserta proyek dapat digunakan untuk memperhitungkan perkembangan ternak yang dipelihara selama paket proyek tersebut direalisasikan yang sangat tergantung pada lamanya keikutsertaan dalam proyek tersebut, seperti terlihat pada Tabel 3 berikut.

Tabel 3 Penguasaan Sumber daya Ternak Proyek PUTKATI

di Propinsi Sulawesi Utara, Gorontalo, dan Sulawesi Selatan

\begin{tabular}{lccccccccccccc}
\hline \multicolumn{1}{c}{ Propinsi } & \multicolumn{1}{c}{ Sulawesi Utara } & \multicolumn{4}{c}{ Gorontalo } & \multicolumn{5}{c}{ Sulawesi Selatan } \\
\hline $\begin{array}{l}\text { Uraian } \\
\text { lokasi }\end{array}$ & $\mathbf{0 1}$ & $\mathbf{0 2}$ & Rataan & $\mathbf{0 3}$ & $\mathbf{0 4}$ & rataan & $\mathbf{0 5}$ & $\mathbf{0 6}$ & $\mathbf{0 7}$ & $\mathbf{0 8}$ & $\mathbf{0 9}$ & Rataan \\
\hline $\begin{array}{l}\text { Keterlibatan } \\
\text { Proyek (tahun) }\end{array}$ & 2 & 4 & - & 4 & 3 & - & 4 & 2 & 3 & 2 & 2 & - \\
\hline
\end{tabular}


Tabel 3 Penguasaan Sumber daya Ternak Proyek PUTKATI

di Propinsi Sulawesi Utara, Gorontalo, dan Sulawesi Selatan (lanjutan)

\begin{tabular}{lcccccccccccc}
\hline jantan dws & 0.33 & 0.28 & 0.30 & 0.28 & 0.28 & 0.28 & 0.33 & - & 0.14 & 0.57 & 0.43 & 0.29 \\
Betina dws & 1.16 & 1.42 & 1.30 & 2.28 & 1.57 & 1.93 & 1.66 & 2.00 & 1.71 & 1.86 & 1.86 & 1.82 \\
jantan md & 0.33 & 0.28 & 0.30 & 0.43 & - & 0.22 & 0.83 & 0.14 & 0.43 & - & 0.14 & 0.31 \\
betina md & 0.66 & 0.71 & 0.69 & 1.00 & 0.28 & 0.69 & 0.83 & 0.57 & 0.29 & 0.57 & 0.14 & 0.35 \\
jantan ank & - & 0.14 & 0.07 & 0.28 & 0.28 & 0.28 & 0.16 & 0.86 & 0.29 & 0.28 & 0.14 & 0.35 \\
betina ank & - & 0.28 & 0.15 & 0.71 & 0.86 & 0.78 & 0.50 & 0.14 & 0.14 & 0.43 & 0.14 & 0.27 \\
\hline Total & 1.40 & 3.11 & 2.18 & 4.98 & 3.27 & 4.18 & 4.31 & 3.71 & 3.00 & 3.71 & 2.85 & 3.39 \\
\hline
\end{tabular}

Keterangan : 01 = Kabupaten Minahasa

$06=$ Kab. Polmas

02 = Kabupaten B. Mongondow

$07=$ Kab. Mamuju

$03=$ Kabupaten Boalemo

$08=$ Kab. Luwu

04 = Kabupaten Gorontalo

$09=$ Kab. Luwu Utara

\section{Dampak Ekonomi Realisasi Proyek PUTKATI}

Dalam menganalisis seberapa besar kontribusi ternak dalam perekonomian petani di pedesaan sebagai langkah program peningkatran pendapatan petani, pendapatan dilakukan melalui pendekatan analisis margin kotor. Penggalian pendapatan petani baik petani peserta proyek maupun petani di luar proyek dikelompokan menjadi 3 komponen penyumbang pendapatan yang dinggap penting yakni, pendapatan usaha pertanian, usaha peternakan, dan usaha lain di luar usaha tani (dagang, buruh tani, dan pekerjaan lainnya). Variasi sumber pendapatan petani tersebut sangat ditentukan oleh potensi suberdaya lahan, skala pemilikan lahan, serta komoditas unggulan yang diusahakan oleh petani. Perhitungan penerimaan usaha peternakan dalam pengamatan itu diperhitungkan dari hasil penjualan ternak oleh petani maupun nilai ternak yang disetorkan kepada proyek yang diperhitungkan nilai saat terjadinya transaksi selama satu tahun terakhir. Pada Tabel 4 berikut disajikan daftar pendapatan kotor peserta Proyek dan bukan peserta Proyek di Propinsi Sulawesi Utara, Gorontalo, dan Sulawesi Selatan. 


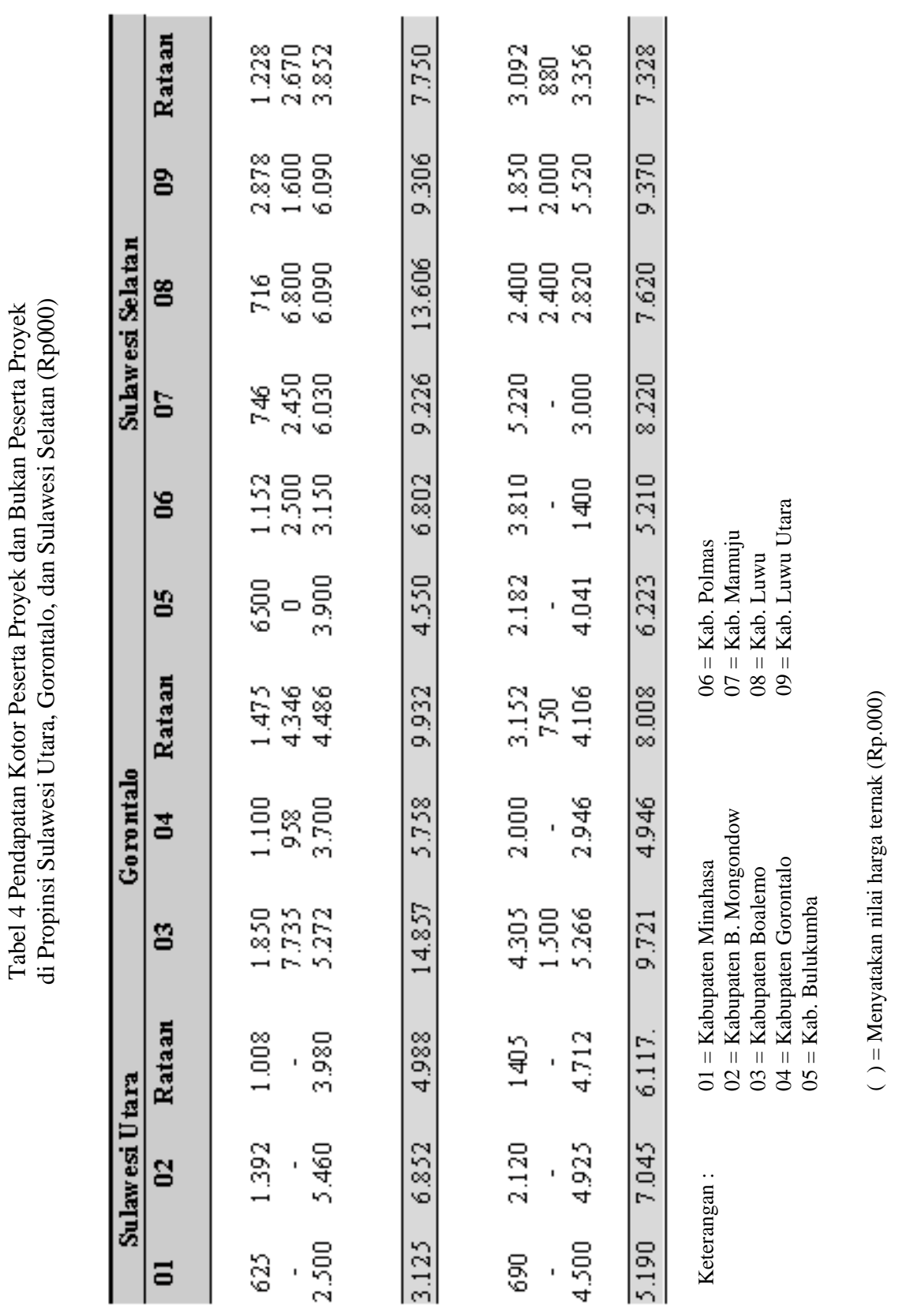




\section{Peningkatan Gizi}

Rata-rata peliharaan ayam oleh Petani pada lokasi sampel bervariasi antara $<10$ ekor ( 40\%) sampai lebih 30 ekor (11.6\%) ayam dewasa. Sisanya memelihara antara 10-30 ekor ayam dewasa (48.4\%) Sistem pemeliharaan umumnya dilepas (tanpa kandang) dinyatakan oleh 49.1\% petani responden, sebagian lagi dilepas dan sore dikandangkan (29.8\%), dan sekitar 8.7\% selalu dikandangkan. Di lokasi Proyek telah dilakukan vaksinasi ND terhadap ayam buras milik petani yang dilakukan oleh petani sendiri (yang sudah dilatih) atau Petugas. Namun demikian, ada lokasi Proyek yang tidak melakukan vaksinasi (salah satu lokasi sampel di Gorontalo dan Sulawesi Selatan, masing-masing dinyatakan oleh $35.7 \%$ responden dan $62.5 \%$ responden). Petani umumnya puas atau cukup puas dengan hasil vaksinasi dan sebagian kecil (9.3\% responden) menyatakan tidak puas.

Peningkatan gizi dan ketahanan pangan didasarkan pada keberhasilan upaya penekanan angka kematian terhadap ND, dengan cara malakukan vaksinasi ND secara berkala dan dengan cara yang benar. Peningkatan gizi keluarga itu bersumber dari dari produk pemeliharaan ayamnya (daging dan telur - langsung) ataupun dari hasil penjualan ayam yang kemudian dibelanjakan untuk keperluan keluarga (tidak langsung). Sebagian hasil pemeliharaan ayam dijual untuk memeperoleh uang tunai yang digunakan untuk keperluan sehari-hari (jumlah terbanyak menjual antara $25 \%-75 \%$ dari hasil keturunannya dinyatakan oleh 48.8\% petani responden). Sisa yang tidak dijual digunakan untuk konsumsi (dinyatakan oleh 67.0\% responden). Dan sebagian untuk bibit pengembangan usaha ternak ayamnya (dinyatakan oleh $4.4 \%$ responden).

Sebagian terbesar responden (74.4\%) menyatakan bahwa ayam bermanfaat untuk meningkatkan gizi keluarga. Kelembagaan di luar Proyek yang berperan dalam urusan peningkatan gizi keluarga adalah Posyandu (dinyatakan oleh 64.4\%) dan PKK (dinyatakan oleh $14.2 \%)$ memegang peranan dalam urusan peningkatan gizi keluarga.

\section{Peningkatan Hasil Pelatihan}

\section{A. Pelatihan Ditingkat Petani-Peternak}

(1) Relevansi pelatihan dengan tugas yang ditekuni.

Hasil pelatihan yang diterima menurut petani-peternak di Propinsi Sulut (100\%) sudah relevan dengan tugas yang ditekuni dengan alasan 73\% membantu usaha dan 82\% sesuai dengan usaha yang ada/ditekuni. Di Propinsi Gorontalo semua petani-peternak (100\%) mengatakan pelatihan yang diterima sudah relevan dengan alasan 71\% membantu usaha dan 21\% sesuai dengan usaha yang ada. Di Propinsi Sulsel mengatakan sudah relevan dengan alasan 73\% membantu usaha dan $30 \%$ sesuai dengan usaha yang ada. Dengan sudah relevannya materi pelatihan dengan tugas yang ditekuni petani maka dapat diharapkan program Putkati berjalan mulus sesuai dengan rencana yang disepakati.

(2) Pemenuhan terhadap target yang ditetapkan proyek.

Hasil pelatihan yang diberikan menurut petani-peternak Sulut $91 \%$ cukup dan 9\% sangat memenuhi target yang direalisasikan dalam Proyek dan 64\% dengan alasan menambah ilmu dan 27\% sesuai dengan yang ada. Di Gorontalo 64\% mengatakan cukup dan 36\% sangat memenuhi target yang direalisasikan dalam proyek dengan alasan 14\% menambah ilmu, 14\% masih perlu pelatihan ulang dan 29\% telah sesuai dengan yang ada. Di Propinsi Sulsel $72 \%$ cukup dan 21\% sangat memenuhi target yang direalisasikan dalam proyek, dengan alasan 30\% menambah ilmu, 
$27 \%$ sesuai dengan yang ada dan 15\% walaupun mengatakan cukup namun masih perlu pelatihan lagi.

(3) Aplikasi pelatihan dalam membantu keberhasilan proyek.

Menurut petani-peternak di Sulut 82\% mengatakan cukup membantu dan 18\% sangat membantu keberhasilan proyek. Di Gorontalo 43\% mengatakan cukup dan 50\% sangat membantu keberhasilan. Di Sulsel 64\% mengatakan cukup dan 36\% sangat membantu keberhasilan proyek.

(4) Penularan hasil pelatihan.

Petani-peternak di Sulut 100\% menularkan kepada petani-peternak tetangga.Di Gorontalo 86\% menularkan ke petani-peternak tetangga dan petani lain, dan 14 mengatakan tidak tahu. Di Sulut $94 \%$ menularkan ke petani lain dan tetangga, dan $6 \%$ mengatakan tidak tahu.

(5) Adopsi dan aplikasi pelatihan oleh petani.

Petani di Sulut 73\% mengatakan cukup, 27\% sangat dapat mengadopsi dengan alasan 73\% petani membutuhkan, dan 36\% karena petani umumnya anggota kelompok tani. Petani di Gorontalo 65\% mengatakan cukup dan 35\% sangat dapat mengadopsi dengan alasan semua petani sudah anggota kelompok tani dan membutuhkan. Di Sulsel 12\% mengatakan cukup dapat dan 88\% sangat dapat mengadopsi dengan alasan hampir semua petani anggota kelompok dan membutuhkan.

(6) Apakah latihan perlu dilanjutkan dengan tambahan materi yang lain.

Petani-peternak Sulut 73\% mengatakan ya dengan alasan perlu diadakan pelatihan IB pada sapi, $27 \%$ mengatakan tidak tahu. Di Gorontalo $86 \%$ ya dengan alasan perlu adanya pelatihan IB pada sapi dan $14 \%$ tidak tahu. Di Sulsel 76\% mengatakan ya dengan alasan diadakan pelatihan IB dan $15 \%$ tidak tahu.

\section{B. Pelatihan Ditingkat Staf Proyek}

(1) Jenis pelatihan yang telah diadakan.

Jenis pelatihan $12 \%$ komputer, $82 \%$ pelatihan PRA, 18\% pelatihan IB, 6\% pelatihan keswan, dan $12 \%$ pelatihan agrobisnis.

(2) Relevansi dengan tugas.

Pelatihan $45 \%$ dikatakan sudah relevan dengan yang dibutuhkan petani, $47 \%$ sesuai dengan tugas Satgas di lapangan.

(3) Pemenuhan terhadap target yang ditetapkan Proyek.

Hasil pelatihan 59\% cukup memenuhi target, 29\% sangat memenuhi target yang direalisasikan dalam proyek, sedangkan 12\% mengatakan masih kurang dan perlu pelatihan kembali. Beberapa alasan yang dikemukan anatara lain materi sudah sesuai dengan rencana proyek, dapat meningkatkan penghidupan petani, memudahkan tugas di lapangan namun belum dapat diterapkan seluruhnya dan masih perlu ditingkatkan serta perlu ada pelatihan kembali.

(4) Pengaplikasian untuk keberhasilan proyek.

Hasil pelatihan 29\% mengatakan sudah cukup membantu dan 71\% sangat membantu keberhasilan proyek. Beberapa alasan yang dikemukakan antara lain membantu kelancaran proyek dan pelaksanaan petugas, meningkatkan partisipasi petani dan memdorong pemberdayaan, membantu pembinaan dan meningkatkan pengetahuan petani. 
(5) Dampak pelatihan terhadap peningkatan profesi dalam promosi jabatan.

Responden $29 \%$ mengatakan ya, $29 \%$ tidak, dan $41 \%$ tidak menjawab. Responden mengatakan ya dengan alasan antara lain dapat mengembangkan karier, sebagai satgas harus mempertahankan nama, memudahkan pelaksanaan di lapangan. Responden mengatakan tidak dengan alasan karena tidak dinilai yang diperhatikan kepangkatan, tidak ada hubungan dan tidak ada kaitannya dengan jabatan.

(6) Penularan hasil pelatihan kepada staf.

Responden 58\% mengatakan ya dan 42\% mengatakan tidak. Responden mengatakan ya alasannya perlu disosialisasikan, bermanfaat bagi semua, lebih cepat mengaplikasikan di lapangan, membantu pembinaan, dan bagi staf dapat mengembangkan hasil pelatihan.

(7) Apakah petani dapat mengadopsi dan mengaplikasikan hasil pelatihan.

Sebanyak 18\% mengatakan kurang dengan alasan perlu binaan karena pendidikan petani kurang dan SDM petani minim, 82\% mengatakan cukup atau lebih dari cukup dengan alasan petani setelah menerima teori selalu diaplikasikan di lapangan, materinya fleksibel, teori yang diterima mudah dimengerti untuk diaplikasikan, pelatihan yang diterima berhubungan dengan kegiatan petani sehari-hari.

(8) Bagaimana sebaiknya disiapkan program pelatihan Proyek untuk waktu mendatang. Jawaban yang diberikan antara lain, yaitu perlu pelatihan pengembangan masyarakat yang merupakan dasar penguatan kelompok, pembentukan tim kerja kelompok karena kesadaran petani masih kurang, pemberdayaan kelompok tani agar dapat mencapai sasaran proyek, penataan administrasi kelompok agar petani tahu perkembangannya, pelatihan IB dan keswan bagi satgas untuk meningkatkan populasi dan kesehatan ternak.

\section{Pengaruh Desentralisasi}

Terbitnya UU No.22/1999 tentang pemerintahan daerah dan UU No.25/1999 tentang perimbangan keuangan pusat dan daerah merupakan gagasan yang inovatif dalam manajemen dan politik pembangunan nasional. Kebijakan tersebut secara substantif memberikan kewenangan kontrol dan distribusi kekuatan politik sebagai refleksi kebutuhan demokratisasi yang lebih luas kepada daerah. Penyelenggaraan otonomi daerah ditempuh melalui pola penyerahan urusan secara total, bulat, utuh, dan menyeluruh, kecuali atas hubungan luar negeri, pertahanan keamanan, peradilan, moneter, dan agama (Nurbaya, 1999). Pemerintah Daerah memiliki keleluasaan yang lebih luas dalam penanganan urusan pemerintah ditingkat lokal, penyelesaian permasalahan daerah, dan dapat lebih kreatif menggali dan mengembangkan potensi daerah untuk kesejahteraan masyarakatnya.

Dari hasil wawancara dengan Bappeda, Pemda, Dinas, dan Proyek, mereka menyatakan terdapat 3 (tiga) alternatif hubungan antara pelaksanaan desentralisasi dengan pelaksaan PUTKATI.

Alternatif pertama. Sebaiknya PUTKATI (hampir $60 \%$ dari responden) masih ditangani sepenuhnya oleh Pusat mengingat hal berikut.

1. Dukungan dana dari Pemda masih sangat terbatas;

2. dukungan sumber daya manusia yang cukup andal masih terbatas;

3. dukungan teknologi dan sarana serta prasarana pengembangan masih terbatas;

4. lingkungan strategis antar daerah dan daerah dan pusat masih belum kondusif; 
5. program dan kegiatan PUTKATI masih belum selesai dan perlu sekali dilanjutkan. Bahkan justru ditindak lanjuti baik oleh Pemda, swasta, dan para petani.

Apabila alternatif itu yang diambil maka diperlukan adanya perbaikan antara lain sebagai berikut.

1. Penentuan jenis ternak dan komoditas terpadu harus disesuaikan dengan keinginan daerah dan petani, agroekologi, kemampuan petani, dan pasar.

2. Kriteria petani penerima bantuan harus jelas dan berdasar atas kriteria daerah.

3. Adanya keterbukaan antara pusat dan daerah.

4. Pemberian informasi dan sosialisasi kegiatan dan pemecahan masalah harus lengkap dan jelas serta transparan.

5. Koordinasi vertikal dan horisontal perlu sering diadakan sesuai kebutuhan.

6. Sistem perencanaan proyek harus disesuaikan dengan kebutuhan petani.

7. Sebaiknya Pemda terlibat langsung dalam proses redistribusi ternak ke penggaduh yang baru.

Alternatif kedua. Hal yang dipilih oleh para responden adalah PUTKATI diserahkan sepenuhnya diserahkan ke Pemda, dengan alasan antara lain sebagai berikut.

1. Sesuai dengan pelaksanaan UU No.22/1999 dan No.25/1999.

2. Bupati bertanggung jawab langsung terhadap pelaksanaan program dan kegiatan PUTKATI

Meskipun begitu, PUTKATI dilaksanakan dengan beberapa perobahan/perbaikan antara lain sebagai berikut.

1. Aturan pembagian hasil antara pusat dan daerah.

2. Hasil penjualan ternak redistribusi harus disetor ke Pemda Tk.II.

3. Pemda harus menyediakan anggaran operasi dan pemeliharaan prasarana dan sarana yang telah dan yang akan dibangun.

4. Struktur TIM Pemandu Kabupaten lebih baik ditentukan oleh Daerah.

5. Perlu disediakan dana khusus untuk aparat Kecamatan ( camat, Kapolsek, Koramil, dan instansi terkait).

6. Menggunakan tenaga PPL untuk Satgas

Sebagai alternatif ketiga. Para responden memberikan pilihan agar sebagian program dan pekerjaan PUTKATI diserahkan kepada Daerah dengan dalih berikut.

1. Pelaksanaan UU No.22 dan $25 / 1999$ dengan kemampuan keuangan dan SDM dari PEMDA yang masih terbatas.

2. Bupati bertanggung jawab langsung terhadap pelaksanaan PUTKATI.

3. Bottom-up planning dan full participatory approach dapat lebih dilaksanakan.

4. Forum Komunikasi perlu dimanfaatkan secara maksimal.

5. Koordinasi proyek dapat dilaksanakan lebih baik.

6. Keterbukaan antara Pusat dan Daerah dapat lebih berjalan dengan baik dan tidak langsung mementingkan diri sendiri.

7. Kebutuhan dana, SDM, teknologi masih dapat disupport dari Pusat.

8. Kebutuhan dan keinginan Daerah dapat lebih terakomodasi 


\section{Pengaruh Kredit}

\section{Perkreditan “in kind”}

Dalam rencana pelaksanaan Proyek PUTKATI yang dikeluarkan bulan Juni 1996 oleh Direktorat Jenderal Bina Produksi Peternakan, Departemen Pertanian, kredit ternak ditetapkan sebagai berikut.

\section{Ternak sapi}

Setiap petani akan memeperoleh 2 ekor ternak betina dewasa dan siap kawin (umur 15-18 bulan). Setiap 5 orang petani akan memperoleh satu ekor pejantan sehingga rasio pejantan dengan betina adalah 1:10. Persyaratan teknis sapi Bali dan sapi Bali mengacu pada petunjuk teknis yang ditetapkan oleh Dirjan Bina Produksi Peternakan.

Secara umum, pola kredit yang dilaksanakan adalah Sumba kontrak (credit in kind) yang setiap ekor ternak yang diterima petani akan mengembalikan dua ekor anak keturunannya pada umur yang sama (15-18 bulan) dalam jangka waktu 7 tahun. Petani yang menerima 2 ekor sapi betina akan mengembalikan 4 ekor anak turunan sedang petani yang menerima 2 ekor sapi betina 1 ekor pejantan akan mengembalikan 5 ekor anak turunan dalam jangka waktu 7 tahun.

Untuk meningkatkan skala usaha tani ternak, dilakukan penjadualan pengembalian (repayment) oleh petani. Anak turunan pertama ditunda pengembaliannya kepada proyek dan anak keturunan betina dipelihara sebagai induk dan yang anakan dapat dijual oleh petani untuk pendapatan petani. Melalui pola kredit tersebut diharapkan petani akan dapat melunasi kredit mereka pada akhir tahun ke 6 atau awal tahun ketujuh

\section{Ternak kambing}

Setiap petani memperoleh 2 ekor kambing betina dewasa dan siap kawin (umur 12-15 bulan). Setiap 5 petani akan menerima satu ekor pejantan sehingga rasio pejantan dengan betina adalah 1:10. Persyaratan teknis kambing yang disebarkan mengacu kepada petunjuk teknis Dirjen Bina Produksi Peternakan. Pola kredit yang dilaksanakan adalah Sumba Kontrak (credit in kind) dan petani akan mengembalikan 2 ekor anak turunan pada umur yang sama terhadap penerimaan satu ekor ternak betina dewasa dalam jangka waktu 3 tahun.

Petani yang menerima 2 ekor kambing betina akan mengembalikan 4 ekor anak turunan pada umur yang sama sedang petani penerima 2 ekor betina dan satu ekor pejantan akan mengembalikan 5 ekor anak turunan dalam jangka waktu 3 tahun. Melalui pola kredit tersebut, diharapkan petani dapat melunasi kredit ternak pada akhir tahun ketiga. Untuk meningkatkan skala usaha tani ternak, pengembalian (repayment) pertama dapat ditunda dan ternak betina terus dipelihara sebagai ternak induk sedang ternak jantan dijual sebagai pendapatan petani.

\section{Realisasi Pembayaran Kembali (Repayment)}

Supervision Report UNOPS (22 June-9 July 2001) menyebutkan bahwa Proyek agaknya tidak terarah dalam pembayaran kredit ternak. Sebagaimana dicantumkan dalam Kontrak dengan Peserta Proyek pembayaran kembali seharusnya terjadi sebelum akhir dari tahun keempat Proyek 
(tahun 2000). Sebagaimana dituangkan dalam rencana pelaksanaan Proyek maka rincian "repayment” sebagai berikut.

1. Untuk kredit sapi

Peserta proyek yang menerima 2 sapi betina dan sekor pejantan akan mengembalikan 5 ekor anak sapi keturunan sekurang-kurangnya berumur 18 bulan pada tahun 2000-2003. Peserta yang menerima 2 sapi betina mengembalikan kredit berupa 4 anak sapi keturunan umur 18 bulan pada tahun 2000-2003.

2. Untuk kredit kambing

Peserta proyek yang menerima 2 kambing betina dan seekor pejantan akan mengembalikan 5 ekor anak kambing sekurang-kurangnya berumur 15 bulan pada waktu 3 tahun. Peserta yang menerima 2 kambing betina mengembalikan kredit berupa 4 anak kambing keturunan umur 15 bulan pada waktu 3 tahun. Data pada Proyek PUTKATI mengenai perkembangan setoran ternak disajikan dalam Tabel 5 berikut.

Tabel 5 Rekapitulasi Perkembangan Setoran Ternak Proyek PUTKATI s.d. Oktober 2001

\begin{tabular}{|c|c|c|c|c|c|c|c|c|c|c|}
\hline No. & Propinsi/ & Jenis & Ras & & & & Realis & & & \\
\hline I & Sulawesi & & & & Redistrib & & & & ijualan & \\
\hline & & & & Jantan & betina & Jumlah & jantan & betina & jumlah & Nilai \\
\hline (1) & (2) & (3) & (4) & (5) & (6) & $(7)$ & $(8)$ & (9) & (10) & (11) \\
\hline 1. & Bulukumba & Sapi & Bali & 32 & 106 & $\underline{138}$ & 0 & 0 & 0 & 0 \\
\hline & & Kambing & $\mathrm{PE}$ & 4 & 14 & 18 & 0 & 0 & 0 & 0 \\
\hline & Sub Total & & & 36 & 120 & 156 & 0 & 0 & 0 & 0 \\
\hline 2. & Polmas & Sapi & Bali & 0 & 0 & 0 & 0 & 0 & 0 & 0 \\
\hline & & Kambing & $\mathrm{PE}$ & 14 & 113 & 127 & 0 & 0 & 0 & 0 \\
\hline & Sub-total & & & 14 & 113 & 127 & 0 & 0 & 0 & 0 \\
\hline 3. & Luwu & Sapi & Bali & 64 & 144 & $\underline{208}$ & 5 & 4 & 9 & $5,597,600$ \\
\hline & & Kambing & PE & 38 & 362 & $\overline{400}$ & 83 & 0 & 83 & $10,696,600$ \\
\hline & Sub-total & & & 102 & 506 & 608 & 88 & 4 & 92 & $16,194,000$ \\
\hline 4. & Mamuju & Sapi & Bali & 6 & 70 & 76 & 0 & 0 & 0 & 0 \\
\hline & & Kambing & $\mathrm{PE}$ & 8 & 22 & $\overline{30}$ & 0 & 0 & 0 & 0 \\
\hline & Sub-total & & & 14 & 92 & 106 & 0 & 0 & 0 & 0 \\
\hline II. & $\begin{array}{l}\text { Sulawesi } \\
\text { Utara }\end{array}$ & & & & & & & & & \\
\hline 5. & Minahasa & Sapi & Bali & 0 & 0 & 0 & 0 & 0 & 0 & 0 \\
\hline & & Kambing & $\mathrm{PE}$ & 0 & 0 & 0 & 0 & 0 & 0 & 0 \\
\hline 6. & Bolaang & Sapi & Bali & 0 & 0 & 0 & 0 & 0 & 0 & 0 \\
\hline & $\begin{array}{l}\text { Mongondo } \\
\mathrm{w}\end{array}$ & Kambing & PE & 0 & 0 & 0 & 0 & 0 & 0 & 0 \\
\hline & Subtotal & & & 0 & 0 & 0 & 0 & 0 & 0 & 0 \\
\hline 7. & Goreontalo & Sapi & Bali & 102 & 194 & 296 & 0 & 0 & 0 & 0 \\
\hline & & Kambing & $\mathrm{PE}$ & 0 & 0 & $\overline{0}$ & 0 & 0 & 0 & 0 \\
\hline
\end{tabular}


Proyek PUTKATI s.d. Oktober 2001 (lanjutan)

\begin{tabular}{llllllrrrr}
\hline Sub Total & 102 & 194 & 296 & 0 & 0 & 0 & 0 \\
\hline TOTAL & 268 & 1025 & 1293 & 88 & & 4 & 92 & $16,194,000$ \\
\hline
\end{tabular}

Sumber data: Laporan Proyek PUTKATI (Oktober 2001)

\section{Pemasaran Ternak}

Survei pemasaran itu diarahkan untuk mengetahui lebih jauh kelembagaan pemasaran ternak yang ada di masing-masimg desa lokasi Proyek seta prospek pengembangannya untuk waktu mendatang. Survei dilakukan di 9 lokasi proyek dengan cara pengumpulan data primer dari responden di tingkat pedesaan. Hasil survei di lokasi ini disajikan dalam table 6 berikut.

Tabel 6 Data Pemasaran Ternak di Lokasi Proyek PUTKATI

\begin{tabular}{|c|c|c|c|c|}
\hline No. & Uraian & $\begin{array}{c}\text { Sulawesi } \\
\text { Utara }\end{array}$ & Gorontalo & $\begin{array}{c}\text { Sulawesi } \\
\text { Selatan }\end{array}$ \\
\hline$(1)$ & (2) & (3) & (4) & (5) \\
\hline \multirow[t]{4}{*}{1.} & $\begin{array}{l}\text { Keberadaan Pasar Hewan di } \\
\text { Kecamatan }\end{array}$ & & & \\
\hline & $\rightarrow$ Ada & 46.2 & 71.4 & 0 \\
\hline & $\rightarrow$ Tidak ada & 53.8 & 14.3 & 78.8 \\
\hline & $\rightarrow \quad$ Tidak tahu & 0 & 14.3 & 21.2 \\
\hline \multirow[t]{4}{*}{2.} & Jarak pasar hewan terdekat & & & \\
\hline & $\rightarrow \quad>10 \mathrm{~km}$ & 46.2 & 28.5 & 51.5 \\
\hline & $\rightarrow \quad 5-10 \mathrm{~km}$ & 23.1 & 42.9 & 9.1 \\
\hline & $\rightarrow \quad<5 \mathrm{~km}$ & 0 & 28.6 & 40.4 \\
\hline \multirow[t]{10}{*}{3.} & Setelah lunas ada rencana dijual & & & \\
\hline & $\rightarrow \quad$ Tidak dijual & 15.4 & 7.1 & 9.1 \\
\hline & $\rightarrow \quad$ Dijual & 84.6 & 35.7 & 54.5 \\
\hline & $\rightarrow \quad$ Tidak tahu & 0 & 57.2 & 36.4 \\
\hline & Alasan & & & \\
\hline & $\rightarrow$ Supaya tidak repot & 15.4 & 14.3 & 21.2 \\
\hline & $\rightarrow \quad$ Tambah penghasilan & 38.5 & 7.1 & 18.2 \\
\hline & $\rightarrow \quad$ Akan dikembangkan & 15.4 & 7.1 & 6.1 \\
\hline & $\rightarrow \quad$ Perlu mendesak & 7.7 & 0 & 0 \\
\hline & $\rightarrow \quad$ Tergantung kebutuhan & 0 & 35.7 & 15.2 \\
\hline \multirow[t]{3}{*}{4.} & Kemana akan dijual & & & \\
\hline & $\rightarrow \quad$ Tengkulak & 76.9 & 46.7 & 87.8 \\
\hline & $\rightarrow \quad$ Tetangga & 0 & 6.6 & 9.1 \\
\hline
\end{tabular}

Evaluasi Ekonomi Mikro: Da mpak Proyek... (Budiman Notoatmojo) 


\begin{tabular}{|c|c|c|c|c|}
\hline & $\rightarrow \quad$ Pasar hewan & 15.4 & 46.7 & 0 \\
\hline & \multicolumn{4}{|l|}{ Alasan } \\
\hline & $\rightarrow \quad$ Belum pernah jual & 7.7 & 0 & 0 \\
\hline & $\rightarrow$ Harga lebih baik & 7.7 & 6.6 & 9.1 \\
\hline & $\rightarrow \quad$ Lebih mudah, dibayar tunai & 61.5 & 21.4 & 69.7 \\
\hline \multirow[t]{6}{*}{5.} & \multicolumn{4}{|l|}{ Penggunaan uang hasil penjualan } \\
\hline & $\rightarrow$ Pendidikan & 7.6 & 35.7 & 36.4 \\
\hline & $\rightarrow \quad$ Usaha tani & 38.5 & 42.8 & 36.4 \\
\hline & $\rightarrow \quad$ Keperluan rumah tangga & 46.2 & 50.0 & 51.5 \\
\hline & $\rightarrow$ Beli tanah & 0 & 14.3 & 0 \\
\hline & $\rightarrow \quad$ Beli ternak & 0 & 14.3 & 0 \\
\hline \multirow[t]{3}{*}{6.} & \multicolumn{4}{|l|}{ Saran untuk pemasaran } \\
\hline & $\rightarrow$ Dibangun pasar hewan & 100 & 100 & 100 \\
\hline & $\rightarrow \quad$ Belum tahu & 0 & 21.4 & 0 \\
\hline
\end{tabular}

Sampai saat ini telah cukup banyak ternak yang dijual (Supervision mission June-July 2001). Di samping itu, menurut hasil survei lapangan sebagian besar peternak responden akan menjual ternaknya setelah lunas. Dengan alasan lebih mudah dan mendapatkan uang tunai, peternak lebih menyukai menjual ternaknya kepada tengkulak. Hal lain yang medorong penjualan ke tengkulak adalah keberadaan Pasar Hewan yang jauh lokasinya (> $10 \mathrm{~km}$ ). Di samping itu, risiko tidak laku dipasar hewan menjadi pertimbngan pula bagi petani untuk memilih menjual lewat tengkulak.

Hasil penjualan ternak sapi pada umumnya digunakan untuk memperoleh uang tunai guna memenuhi kebutuhan rumah tangga (menigkatkan pendapatan). Beberapa responden menyatakan hasil penjualan ternak untuk keperluan pengembangan usaha tani, pendidikan, beli tanah, ataupun beli ternak. Masalah keinginan peserta Proyek untuk menjual ternaknya setelah lunas perlu diwaspadai dan perlu diupayakan langkah pengamannya sehingga dampak positif Proyek tidak hilang demikian saja. Masalah "sustainability Proyek" perlu digali di lapangan dengan mengidentifikasikan potensi yang ada yang telah dicapai oleh petani, kelompok, desa, dan selanjutnya mengembangkan SDA dan SDM yang ada tersebut ke tingkat pengembangan berikutnya (misalnya, pengembangan usaha bersama dengan maksud meningkatkan skala usaha dengan pendekatan agrobisnis).

\section{Peranan Lembaga Keuangan Pedesaan}

Sejauh ini, di lokasi proyek PUTKATI hanya terdapat satu sistem perkreditan, yaitu perkreditan yang dilaksanakan oleh Proyek berupa “credit in kind”. Sistem perkreditan dan pola komponren paket ( 2 betina, serta 2 betina +1 pejantan untuk setiap 5 peseta kredit) cukup layak bagi petani kecil yang dilihat dari aspek kemapuan permodalan usaha digolongkan "golongan ekonomi lemah”. Kredit itu diberikan tanpa agunan serta disertai bimbingan teknis kepada penerima paket kredit, pemantapan dan pengembangan peranan kelompok dalam berproduksi dan memasarkan produk. 
Dari hasil wawancara dengan peserta Proyek yang diadakan di 3 Propinsi mengungkapkan bahwa petani lebih menginginkan "credit in kind", hanya beberapa peatani di lokasi sampel di Gorontalo yang menyatakan kemungkinan pengembalian "finansial" (dinyatakan oleh 7.1\% responden). Selanjutnya, survei lapangan yang dilakukan di 9 (sembilan) lokasi Proyek menunjukkan bahwa sampai saat ini belum ada Lembaga Keuangan Desa ( BRI Unit Desa ataupun Koperasi) yang berkembang baik. Dengan demikian, urusan yang berkaitan dengan sistem perkreditan lain selain sistem gaduhan/ "credit in kind" ( yaitu, kredit semi gaduhan/ "modified in kind” ataupun kredit finansial) belum ada Lembaga yang dapat mengelolanya.

Belum semua Kelompok Petani dapat berperanan penuh pada pengelolaan kredit ternak. Peranannya dalam sistem perkreditan ternak masih sangat minim, kalau tidak dikatakan tidak ada. Sejauh ini, di desa lokasi Proyek PUTKATI belum ada ataupun belum berkembang Lembaga Keungan Pedesaan. Pada perkembangan selanjutnya, yaitu pada saat usaha tani terpadu sebagaimana dirancang Proyek ini telah berhasil dengan baik, pada saat akan mengembangkan usaha tani dengan pendekatan asgribis, kiranya keberadaan dan peranan Lembaga Keuangan Desa perlu digali dan dicari jalan untuk mengembangkannya karena peluang untuk itu telah memungkinkan. Dengan adanya Lembaga tersebut, sistem perkreditan semi gaduhan ("modified in kind”) dan sistem kredit finansial (yang lazim disalurkan sebagai kredit usaha melalui jalur perbankan) dapat merupakan pilihan alternatif untuk perluasan “coverage” penyebaran ternak.

\section{Analisis Dampak Kegiatan Proyek PUTKATI}

Dalam menganalisis dampak proyek PUTKATI dilakukan dengan analisis regresi multifaktor dengan mempertimbangkan data "ex-ante dan ex-post analisis" terhadap petani yang terlibat dalam proyek tersebut yang berpatokan pada peningkatan total pendapatan keluarga petani proyek sebelum dan sesudah mengelola paket proyek (agro-input). Karena data ex-ante usaha tani sulit didapatkan akibat kurangnya data perencanaan dalam kegiatan proyek, data tersebut diambil (diwakili) oleh data peternak nonproyek yang diasumsikan bahwa informasi tersebut dapat mewakili data awal petani proyek sebelum dilakukan implementasi paket proyek yang direkomendasikan. Persamaan yang direkomendasikan sebagai berikut.

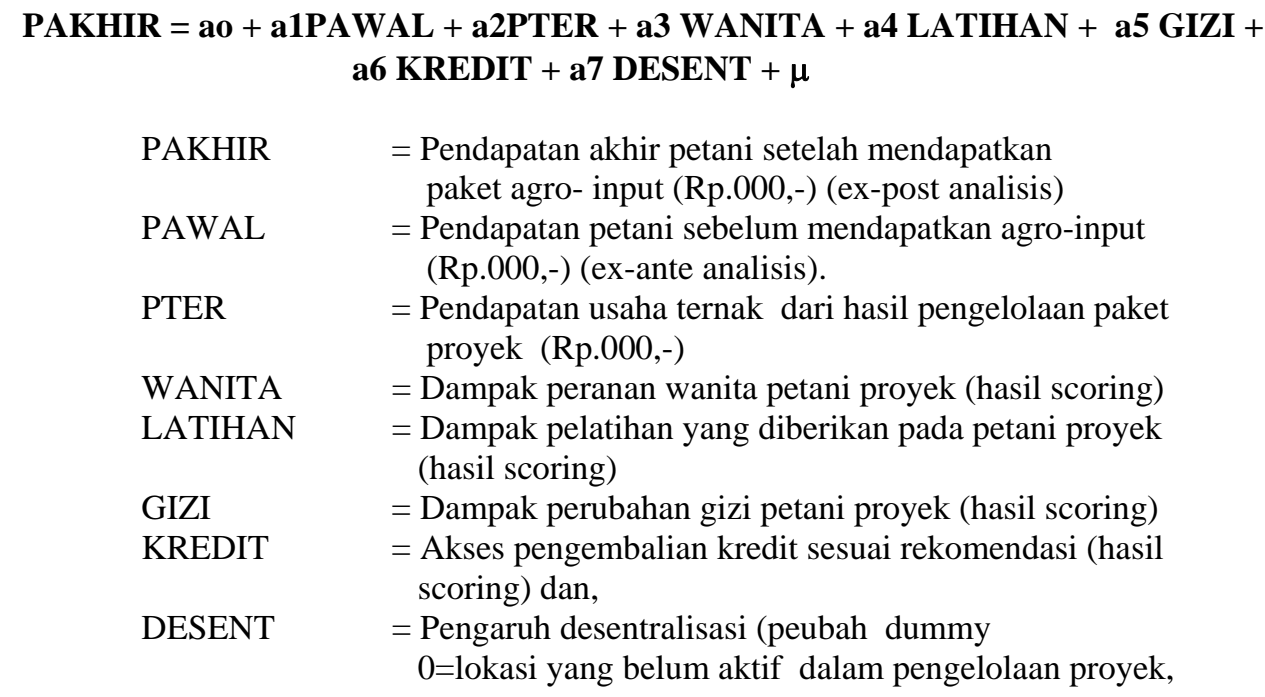




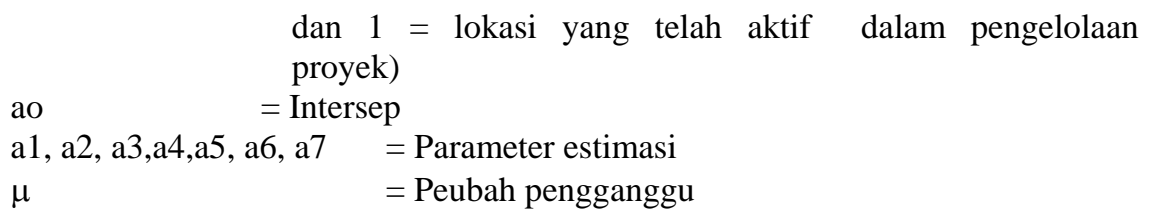

Dalam analisis pendapatan tersebut, pendapatan petani diperhitungkan dengan pendekatan analisis margin kotor (gross margin analysis) yang dikelompokkan dalam pendapatan usaha ternak yang dipandang merupakan paket proyek utama (ternak sapi), serta total pendapatan yang merupakan gabungan pendapatan dari pendapatan usaha pertanian, usaha ternak dan usaha di luar usaha tani (non farm income). Pendapatan usaha ternak diperhitungkan dari hasil penjualan ternak, maupun nilai jual ternak yang telah disetorkan oleh petani yang dinilai pada saat transksi terjadi. Peranan wanita dalam menunjang usaha keluarga, dampak pelatihan, peningatan gizi keluarga dan perkreditan dilakukan penilain (scoring) dari hasil wawancara terhadap petani dengan nilai maksimal adalah 100 dan minimal adalah 0. Pengaruh desentralisasi dalam analisis ini dinyatakan sebagai "dummy variable" dan nilai 0 adalah dinyatakan sebagai wilayah yang belum terlibat langsung dalam kegiatan proyek PUTKATI sedangkan nilai 1 adalah lokasi yang telah ikut aktif dalam kegiatan proyek dengan asumsi bahwa lokasi tersebut telah aktif dalam pelaksanaan program desentralisasi.

Hasil analisis (Tabel 1) menunjukkan bahwa nilai koefisien detereminasi (R2) dalam persamaan yang dibentuk sebesar 0.70. Hal tersebut menunjukkan bahwa 70 persen peubah bebas (independent variable) yang dimasukkan dalam model tersebut mampu menjelaskan peubah tidak bebas (dependent variable) dalam persamaan yang dibentuk sedangkan 30 persen lainnya dipengaruhi oleh faktor lain di luar model persamaan. Terlihat bahwa pendapatan petani sebelum mendapatkan paket proyek (agro input) yang diistribusikan sangat nyata $(\mathrm{P}<0.01)$ berpengaruh positif terhadap total pendapatan akhir petani setelah mendapatkan sarana agro input yang direalisasikan dalam proyek PUTKATI. Kondisi demikian berarti dengan meningkatnya pendapatan petani sebelum mendapatkan sarana agro-input akan meningatkan pula pemdapatan akhir setelah petani mengelola sarana agro-input yang direalisasikan dalam proyek tersebut. Hal tersebut menunjukkan bahwa pengamatan ekonomi pada kondisi ex-ante analisis cukup berperan dalam menunjnag pendapatan akhir petani proyek.

Pendapatan tersebut tercermin dari besarnya aktivitas dalam usaha tani maupun pendapatan di luar usaha pertanian (nonfarm income) yang cukup potensial di semua lokasi proyek diantaranya adalah usaha buruh tani, sebagai pedagang, dan usaha lainnya. Potensi sumber daya lahan yang menjadikan syarat dalam realisasi proyek (pemilihan kooperator) yang cukup potensial dalam menunjang pendapatan petani di lapangan. Dicerminkan pula dari hasil pengelompokan pendapatan kotor petani yang cukup dominan adalah pendapatan di luar usaha tani maupun usaha pertanian. Pendapatan usaha pertanian yang sangat menonjol adalah usaha perkebunan yakni perkebunan coklat, selain hasil pertanaman komoditas padi dan palawija. Sarana minimal pemilikan lahan pertanian yang dikuasai petani cukup memberikan gambaran penunjang pendapatan petani dan sekaligus juga sebagai sarana penunjang dalam pengembangan agro-input yang dikelola petani, khususnya dalam rangka peningkatan pendapatan petani.

Dampak paket proyek berupa paket ternak khususnya ternak sapi sangat mendukung petani dalam menunjang total pendapatan petani proyek. Hal tersebut dapat ditunjukkan dari hasil analisis bahwa pendapatan usaha ternak nyata $(\mathrm{P}<0.10)$ berpengaruh positif terhadap total pendapatan petani proyek yang hal tersebut menunjukkan bahwa dengan meningkatnya 
pendapatan usaha ternak maka akan meningkatkan pula total pendapatan petani proyek. Peranan ternak sapi pada kondisi petani proyek cukup potensial dalam mendukung pendapatan karena disamping petani dapat memperoleh hasil dari penjualan ternak, juga dari upah tenaga kerja ternak yang dikelola sebagai sarana pengolah lahan pertanian maupun sebagai alat angkut (transportasi) yng merupakan tambahan pendapatan petani.

Pengaruh lokasi pengamatan, lamanya pengelolaan proyek serta bangsa sapi yang dikembangkan, sangat berpengaruh terhadap pendapatan usaha ternak. Pada kondisi pengelolaan yang sudah sekitar 3 tahun lebih cenderung ternak sudah bereproduksi dengan baik sehingga ada kecenderungan petani telah mendapatkan hasil anak (pedet) dan telah banyak dilakukan penjualan maupun pengembalian sebagai redistribusi untuk dikembangkan ke peternak lain. Pada wilayah yang memiliki kondisi agro-ekosistem yang mendukung dalam usaha ternak khususnya yang memiliki areal agro-ekosistem lahan persawahan, kondisi ternak yang dipelihara oleh petani dapat berkembang lebih bagus dibanding dengan lokasi lain yang kondisi agro-ekosistem lahan tegalan. Hal tersebut tidak terlepas dari daya dukung pakan yang cukup berperan dalam pengembangan usaha ternak, disampng kondisi sosial ekonomi masyarakat petani sendiri dan penduduk transmigran cenderung akan lebih berhasil dalam pengelolaan ternak dibanding penduduk lokal.

Bangsa ternak sapi yang didistribusikan juga cukup berperan dalam program pengembangan dan tingkat keberhasilan petani dalam pengelolaan paket proyek. Sapi Peranakan Ongole (PO) terlihat kurang berkembang dibandingkan bangsa Sapi Bali dan hal tersebut ditunjukkan adanya perkembangan eksterior ternak yang tampak kurus serta daya reproduksinya cenderung rendah. Kondisi demikian tidak terlepas dari sifat ternak sapi PO yang cenderung kurang berkembang pada kondisi pakan yang kurang mendukung sedangkan kondisi sebaliknya pada sapi Bali yang relatif lebih tahan pada kondisi pakan yang kurang mendukung.

Tabel 7 Hasil Analisis Faktor yang Dianggap Berpengaruh terhadap Total Pendapatan Akhir Petani Proyek PUTKATI

\begin{tabular}{llll}
\hline \hline Peubah & $\begin{array}{l}\text { Parameter } \\
\text { Dugaan }\end{array}$ & Prob> ITI & Ket. \\
\hline Intersep & -26558 & 0.3044 & tn \\
\hline Pendapatan awal petani & 0.8463 & 0.0018 & $\mathrm{~N}$ \\
\hline Perdapatan usaha ternak & 1.2244 & 0.0730 & $\mathrm{~N}$ \\
\hline Peranan wanita & 16.8377 & 0.4324 & tn \\
\hline Pelatihan & -12.5063 & 0.9413 & tn \\
\hline Peningkatan gizi & -37.9838 & 0.6011 & tn \\
\hline Perkreditan & 391.7374 & 0.1224 & tn \\
\hline Desentralisasi & -1680.0886 & 0.4112 & tn \\
\hline & Koefisien determinasi & & \\
\hline \hline
\end{tabular}

Keterangan : tn = tidak berbeda nyata, dalam taraf nyata 10 persen $(\mathrm{P}>0.10)$

$\mathrm{N} \quad=$ Berbeda nyata dalam taraf 10 persen $(\mathrm{P}<0.10)$

Peranan wanita dalam hal pengelolaan paket proyek berpengaruh positif terhadap total pendapatan keluarga, walaupun tidak menunjukkan perbedaan nyata $(\mathrm{P}>0.10)$. Hal tersebut 
menunjukkan bahwa dengan direalisasikannya proyek maka peranan wanita akan mengalami peningatan khsususnya dalam pengelolaan paket usaha ternak sehingga akan meningkatkan pendapatan keluarga. Program pelatihan yang di rekomendasikan dalam proyek juga akan berimbas kepada peranan istri petani sehingga akan lebih berperan dalam proses pengambilan keputusan dalam berusaha dan cenderung akan menambah aktivitas kerja yang berdampak pada peningkatan pendapatan keluarga. Dengan semakin meningkatnya aktivitas suami dalam hal pengelolaan paket proyek, terdapat hal tertentu yang tidak dapat diselesaikan oleh suami dan hal tersebut akan mendorong pihak istri untuk lebih berperan aktif dalam menunjang aktivitas suami khususnya dalam hal pemberian pakan terhadap ternak maupun aktivitas lainnya di sektor pertanian. Kenyataan menunjukkan bahwa dengan adanya paket proyek maka cenderung akan meningkatkan frekuensi aktivitas keluarga petani dan akan berdampak pula dalam distribusi pendapatan keluarga.

Dampak pelatihan tidak memberikan pengaruh yang signifikan $(\mathrm{P}>0.10)$ terhadap total pendapatan keluarga petani (dampak perkembangan proyek) bahkan hasil analisis menunjukkan hubungan yang negatif. Dampak pelatihan memang kenyataan akan meningkatkan pengetahuan dalam hal sistem usaha pertanian yang direkomendasikan. Akan tetapi, dalam paket proyek yang menonjol dan dengan cepat dirasakan dapat langsung menyumbangkan pendapatan adalah usaha ternak sapi sedangkan paket pelatihan tersebut adalah pelatihan pertanian secara umum. Kondisi demikian kurang berpengaruh nyata terhadap peningkatan pendapatan petani.

Ditinjau dari persepsi petani dalam evaluasi pelatihan petani cukup responsif dan memperoleh dampak informasi tentang pengelolaan usaha pertanian tetapi tidak memberikan dampak langsung terhadap peningkatan pendapatan karena petani pada dasarnya sudah memiliki dasar pengetahuan tentang usaha tani yang berdampak langsung terhadap kelangsungan usaha keluarga. Dampak pelatihan hanya memberikan rangsangan terhadap petani melalui adopsi teknologi yang diberikan dalam pelatihan tetapi kenyataan dalam praktek (action) petani sudah memiliki dasar tentang cara berusaha dalam pengelolaan sumber daya yang dimiliki. Walaupun kondisinya demikian, dari pihak petani program pelatihan masih cukup diperlukan oleh petani sebagai ajang diskusi dalam hal pemecahan permasalahan usaha pertanian secara umum, serta sebagai wahana kerkomunikasi di samping refresing petani kibat kejenuhan dalam aktivitas rutin.

Dalam pengelolaan paket proyek secara umum ada kecenderungan dalam peningkatan gizi petani. Hal tersebut ditunjukkan dalam analisis terdapat hubungan yang negatif $(\mathrm{P}>0.10)$ antara peningkatan gizi dengan peningkatan total pendapatan petani. Kondisi demikian mencerminkan bahwa ada tambahan pendapatan yang dibelanjakan untuk keluarga dalam rekomendasi perbaikan gizi keluarga. Dengan meningkatnya gizi keluarga maka akan menurunkan total income petani atau dengan kata lain terdapat sebagian pendapatan petani yang digunakan untuk menambah pengeluaran dalam perbaikan gizi keluarga dan hal tersebut karena sebagai akibat lebih meningkatnya total pendapatan keluarga petani sebagai dampak pengelolaan proyek tersebut.

Kenyataan di lapangan selain perbaikan gizi dari pengeluaran pendapatan petani, juga ada kecenderungan bahwa petani proyek banyak yang memelihara ternak ayam buras sebagai usaha sambilan penunjang gizi keluarga dibanding petani nonproyek. Hasil usaha ternak ayam buras tersebut khususnya untuk dilakukan pemotongan sebagai konsumsi keluarga pada kondisi skala pemeliharaan yang relatif kecil tetapi dalam kondisi pemeliharaan induk di atas 10 ekor/petani ada kecenderungan untuk dilakukan penjualan dalam menambah pendapatan keluarga di samping sebagai penambah gizi keluarga, sebagai akibat adanya dukungan instansi secara tidak langsung 
karena adanya aktivitas binaan proyek PUTKATI di lokasi, seperti binaan vaksinasi ayam dan lain sebagainya.

Ditinjau dari sistem perkreditan yang ada di wilayah pengembangan proyek nampak belum menunjukkan perkembangan yang signifikan, hanya terbatas pada aktivitas arisan kelompok maupun sistem simpan pinjang yang dikelola oleh organisasi kelompok sesuai dengan keaktifan kelompok yang bersangkutan. Akan tetapi, dilihat dari respon petani dalam pengembalian paket kredit cukup potensial dalam proses pengembalian sesuai dengan perjanjian yang telah disepakati antara pihak petani proyek dengan pihak pengelola proyek. Hasil analisis menunjukan bahwa terdapat hubungan positif $(\mathrm{P}>0.10)$ antara respon petani terhadap realisasi pengembalian kredit dengan pendapatan patani pada akhir proyek. Hal tersebut berarti semakin tinggi minat petani dalam palaksanaan pengembalian kredit maka semakin memacu pengelolaan agro-input sehingga akan memacu pendapatan keluarga petani. Dapat digambarkan pada kondisi petani dan dibeberapa lokasi petani cenderung memacu pengembalian kredit atas hasil keturunan ternak yang dipelihara untuk cepat lunas kemudian baru hasil akhir setelah lunas adalah sepenuhnya hasil petani yang merupakan pendapatan yang oleh petani dinyatakan sebagai keuntungan akhir.

Dampak desentralisasi tidak menunjukkan signifikansi yang cukup berarti $(\mathrm{P}>0.10)$ yang bahkan memiliki hubungan negatif dengan total pendapatan petani pada akhir proyek. Dalam pengelompokan variabel dummy dalam proses desentralisasi dibedakan dalam dua permasalahan yakni desentralisasi diartikan bahwa pemerintah daerah sudah terlibat langsung dalam kegiatan proyek PUTKATI dan belum terlibat langsung. Hasil analisis menunjukkan bahwa proses keterlibatan pemerintah daerah bahkan akan menurunkan tingkat pendapatan petani walaupun tidak menujukkan perbedaan yang nyata $(\mathrm{P}>0.10)$. Hal demikian terdapat indikasi bahwa proses desentralisasi tidak banyak berdampak positif terhadap proses keberhasilan proyek tersebut, khususnya dilihat dari peningkatan pendapatan petani proyek.

Dalam kasus proses desentralisasi dalam realisasi keberlanjutan proyek PUTKATI terdapat beberapa wilayah yang menyatakan bahwa pelaksanaan proyek tersebut sebaiknya ditangani oleh pihak pemerintah pusat. Hal tersebut tidak terlepas dari sistem pembiayaan oleh pemerintah daerah yang masih belum siap karena keterbatasan anggaran yang dimiliki oleh pemerintah daerah. Kondisi demikian masih perlu realisasi pemikiran jangka panjang tentang keberlanjutan proyek dimasa yang akan datang yang perlu dibahas oleh beberapa pihak penentu kebijakan khususnya dalam hal yang menyangkut proses pembiayaan proyek dan realisasi kebijakan “Otonomi Daerah” yang menyangkut kewenangan pemerintah Pusat dan daerah.

\section{PENUTUP}

\section{Simpulan}

1. Sumbangan usaha ternak bagi petani peserta proyek cukup banyak membantu pendapatan keluarga. Tingkat pendapatan petani proyek tampak lebih tinggi dibanding petani bukan peserta proyek. Hal tersebut terjadi pada lokasi wilayah yang pengelolaan usaha ternaknya cukup berhasil sehingga lebih berkesempatan dalam hal penjualan ternak hasil keturunannya yang cukup dominan dalam menyumbang pendapatan. 
2. Dampak proyek dalam pengembangan usaha ternak dapat dirasakan petani, selain dapat menikmati hasil penjualan ternak, petani juga dapat memanfaatkan tenaga dan pupuk kandang untuk melakukan efisiensi biaya produksi tanaman yang dibudidayakan. Di lain pihak, pada kondisi wilayah tertentu ternak masih merupakan simbul status sosial di masyarakat.

3. Perkembangan ternak tampak bervariasi diantara lokasi pengamatan dan di Proipinsi Sulawesi Utara tampak kurang berhasil dibandingkan dengan Propinsi Gorontalo dan Sulawesi Selatan. Hal tersebut ditunjukkan adanya peningkatan populasi yang kurang berkembang serta kemampuan petani yang kurang berminat tinggi dalam usaha. Keberhasilan pengelolaan paket proyek ditunjukkan adanya tingginya penjualan ternak keturunannya maupun realisasi pengembalian ternak secara tepat waktu sesuai dengan kesepakatan sebelumnya.

4. Permasalahan yang dihadapi dalam program pengembangan usaha ternak diantaranya adalah ternak yang disebarkan umumnya masih terlalu muda sehingga petani harus membesarkan terlebih dahulu untuk siap dikawinkan, sistem perkawinan yang terkait dengan pengetahuan petani dalam manajemen perkawinan yang masih rendah perlu ditingkatkan, dan ditunjang keberadaan pejantan di lokasi proyek.

5. Di lokasi Proyek telah dilakukan vaksinasi ND terhadap ayam buras milik petani yang dilakukan oleh petani sendiri (yang sudah dilatih) atau Petugas. Namun demikian, ada lokasi Proyek yang tidak melakukan vaksinasi (salah satu lokasi sampel di Gorontalo dan Sulsel, masing-masing dinyatakan oleh $35.7 \%$ responden dan $62.5 \%$ responden). Petani umumnya puas atau cukup puas dengan hasil vaksinasi dan sebagian kecil (9.3\% responden) menyatakan tidak puas.

6. Sebagian terbesar responden (74.4\%) menyatakan bahwa memelihara ayam bermanfaat untuk meningkatkan gizi keluarga. Kelembagaan di luar Proyek yang berperan dalam urusan peningkatan gizi keluarga adalah Posyandu (dinyatakan oleh 64.4\%) dan PKK (dinyatakan oleh $14.2 \%$ ) memegang peranan dalam urusan peningkatan gizi keluarga

7. Wanita tani cukup besar peranannya dalam aspek keuangan dan perencanaan kebijakan dan pelaksanakan memutuskan dan tugas usaha tani. Fungsi bapak tani lebih berperan dalam pengadaan faktor produksi dan menentukan macam komoditi yang diusahakan. Dalam kegiatan proyek (seperti dalam pengelolaan paket sapi dan kambing), peran wanita tani adalah dalam pemeliharaan; dalam hal kegiatan pedesaan, para wanita tani sangat berperan secara aktif, seperti PKK dan sebagainya. Peranan wanita tani untuk membantu menambah pendapatan keluarga sangat dominan (berdagang dan beternak).

8. Pelatihan petani dinilai cukup membantu keberhasilan proyek namun mengharapkan tambahan materi lain untuk pelatihan selanjutnya (antara lain pelatihan IB).

9. Pelatihan bagi staf proyek dinilai oleh peserta umunya cukup membantu dalam keberhasilan proyek namun disarankan untuk menmperoleh pelatihan lebih lanjut tentang keswa, IB, dan dirasakan perlunya sekolah lapang, jenis pelatihan ditentukan peserta sesuai kebutuhan yang berkesinambungan.

10. Hampir $60 \%$ responden lebih menghendaki agar PUTKATI tetap dikelola oleh Pusat, mengingat Daerah belum cukup mempunyai sumber daya tenaga yang andal, dan kemampuan keuangan Daerah yang masih terbatas. Propinsi Gorontalo hampir $100 \%$ mereka 
menghendaki agar PUTKATI tetap ditangani Pusat sepenuhnya. Di sisi lain, Sulut menghendaki agar PUTKATI sepenuhnya ditangani Derah, sesuai dengan semangat UU No.22 dan 25 /1999. Sulawesi Selatan mengharapkan sebagian komponen penangnanan Proyek diserahkan Daerah dan Pusat bertanggung jawab sepenuhnya dalam realisasi dan pertanggung jawaban Proyek.

11. Posisi perkembangan Proyek PUTKATI dalam implementasi sistem dan pola perkreditan sapi dan kambing adalah sebagai berikut. (a) Repayment masih kecil (dari 26.218 ekor sapi yang disebarkan baru 718 ekor yang disetorkan; dari 18.301 ekor kambing yang disebarkan baru 575 ekor keturunan yang disetorkan); (b) Angka kelahiran rendah (sapi 16.8\% dan domba 37.5\% ). (c) Angka kematian tinggi (sapi 13.4\% dan kambing 43.8\% dari total populasi). (d) Tingkat kehilangan sapi $2.7 \%$ dan kambing 1.9\% dari total populasi. (e) Tingkat penjualan ternak cukup tinggi (Bolaang Mongondow 63.8\%, yaitu dari 47 keturunan pertama 30 ekor dijual).

12. Sampai saat ini telah cukup banyak ternak keturunan yang dijual. Dengan alasan lebih mudah dan mendapatkan uang tunai maka peternak lebih menyukai menjual ternaknya kepada tengkulak. Hal lain yang mendorong penjualan ke tengkulak adalah keberadaan Pasar Hewan yang jauh lokasinya (> $10 \mathrm{~km}$ ). Di samping itu, risiko tidak laku dipasar hewan menjadi pertimbangan pula bagi petani untuk memilih menjual lewat tengkulak. Hasil penjualan ternak sapi pada umumnya digunakan untuk memperoleh uang tunai guna memenuhi kebutuhan rumah tangga (meningkatkan pendapatan). Beberapa responden menyatakan hasil penjualan ternak untuk keperluan pengembangan usaha tani, pendidikan, beli tanah, ataupun beli ternak.

13. Hasil Analisis dampak dengan metode regresi berganda menunjukan bahwa kegiatan PUTKATI berpengaruh positif terhadap peningkatan total pendapatan petani proyek. Peningkatan pengelolaan usaha tani ternak akan sangat berbeda nyata dalam meningkatkan pendapatan total petani. Peranan gender dan pelatihan memberikan sharing yang besar terhadap pendapatan total. Peranan gizi ternyata memberikan indikator yang cukup baik untuk proyek. Untuk petani penerima paket proyek akan memberikan dampak baik dalam peningkatkan gizi keluarga. Untuk masalah desentralisasi, dari hasil analisis dan kenyataan lapang menunjukan efek negatif terhadap peningkatan pendapatan total petani

\section{Saran}

1. Kegitan vakvinasi agar dilakukan disemua lokasi Proyek secara berkala dan dengan cara yang benar. Pelaksanaan vaksinasi seyogyanya makin bertumpu kepada kekuatan serta kemapuan masyarakat petani sendiri. Kegiatan itu dan juga kegiatan pengelolaan ternak kecil diarahkan dalam rangka meningkatkan peranan wanita dalam pencapaian tujuan dan sasaran proyek.

2. Dalam rangka mendukung kemampuan petani untuk melunasi kreditnya disarankan untuk meningkatkan kegiatan penyuluhan, bimbingan, dan pendekatan persuasif yang kontinu sebagaimana diharapkan petani responden, yaitu agar ternaknya dapat beranak 'setiap tahun'. Di samping itu, program redistribusi perlu dijabarkan dalam "format" yang mudah dapat dicerna oleh Petani-Kelompok-Petugas (semacam "Buku Pinter yang berisi antara lain jadwal distribusi masing-masing Petani dan catatan permasalahannya”). Perlu diadakan monitoring, evaluasi perkembangan, identifikasi permasalahan secara lebih tajam serta hasil pemecahan masalah. Untuk mempercepat pemecahan masalah, dalam hal yang sangat penting diadakan "Rapid Assistance Strategy" dengan mengadakan kunjungan langsung di lokasi dan 
mengadakan pertemuan khusus dengan pihak yang dinilai dapat memecahkan permasalahan secara cepat.

3. Masalah keinginan peserta Proyek untuk menjual ternaknya setelah lunas perlu diwaspadai dan perlu diupayakan langkah pengamanannya sehingga dampak positif Proyek tidak hilang demikian saja. Masalah "sustainability Proyek" perlu digali di lapangan dengan mengidentifikasikan potensi yang ada yang telah dicapai oleh petani, kelompok, desa, dan selanjutnya mengembangkan SDA dan SDM yang ada tersebut ke tingkat pengembangan berikutnya secara horizontal (perluasan areal pengembangan) ataupun secara vertikal (pengembangan usaha bersama dengan maksud meningkatkan skala usaha dengan pendekatan “agrobisnis").

4. Disarankan agar dilakukan identifikasi yang mendalam mengenai "training need" pelatihan lanjut untuk petani dan staf proyek, terutama dikaitkan dengan materi pelatihan yang terkait banyak dengan masalah pengembangan ternak (antara lain, IB-Manajemen reproduksi, penanganan kemajiran).

5. Dalam rangka "desentralisasi" disarankan untuk mengadakan identifikasi, monitoring, dan evaluasi secara lebih cermat lagi mengenai minat dan kemampuan daerah untuk pelaksanaan Proyek PUTKATI. Selanjutnya dari hasil analisis identifikasi, monitoring, dan evaluasi tersebut diformulasikan dijabarkan program pembinaannya sehingga pada saatnya Daerah akan mampu mengelola dan mengembangkan Proyek PUTKATI dengan sebaik-baiknya.

6. Dari hasil analisis regresi linier berganda, sangat disarankan agar proyek lebih meningkatkan peranan gender dalam setiap kegiatan proyek. Di samping itu, peranan pelatihan agar dilakukan studi/RRA mengenai training needs dan training strategy sehingga kegiatan pelatihan sesuai dengan kebutuhan petani, pejabat, dan konsumen lainnya 


\section{DAFTAR PUSTAKA}

Anonim. 2002. Laporan Perkembangan Proyek Putkati, Dinas Pertanian Propinsi Maluku Tenggara.

_ 2002. Laporan Perkembangan Proyek Putkati, Dinas Pertanian Propinsi Maluku Tenggara.

2002. Laporan Perkembangan Proyek Putkati, Dinas Pertanian Propinsi Sulawesi Utara. 2002. Laporan Perkembangan Proyek Putkati, Dinas Pertanian Propinsi Gorontalo.

2002. Laporan Perkembangan Proyek Putkati, Dinas Peternakan Propinsi Sulawesi Selatan.

. 2002: Laporan Perkembangan Proyek Putkati Pusat, Dit.Jen Peternakan, Deptan, Jakarta. 2000. Laporan UNOPS, IFAD -ADB.

Notoatmojo, Budiman. 2002. Gender Analisis di Putkati. Jakarta. 